\title{
SEASONAL BIOAVAILABILITY OF HEAVY METAL CONTAMINANTS FROM THE UNIVERSITY OF LAGOS LAGOON, NIGERIA
}

\author{
*Kehinde Sowunmi, Soyebo Titilayo \& Lukman Sowunmi \\ *Department of Cell biology and Genetics, University of Lagos, Akoka, Yaba, Nigeria \\ Department of Applied Science, Ladoke Akintola University of Technology, Ogbomoso, Nigeria
}

\begin{abstract}
Heavy metals have been implicated as Lagoon pollutants from sources such as agriculture, mining and manufacturing industries and waste water treatment works. A study was carried out in the University of Lagos lagoon to investigate the seasonal bioavailability of the heavy metal contaminants $\mathrm{Cd}, \mathrm{Cr}, \mathrm{Cu}, \mathrm{Pb}$ and $\mathrm{Zn}$. The physical parameters $\mathrm{pH}$, redox potential, temperature, TDS and conductivity were measured on site. Dried sediment samples were extracted using the Community Bureau of Reference (BCR) sequential procedure and analysed by ICP-OES. A certified reference material (CRM), BCR 701 (lake sediment) was used for quality assurance with recoveries ranging between $80-120 \%$. Statistical analysis (ANOVA) showed that there was a significant difference between metal distribution in the dry and wet seasons. $\mathrm{Cu}, \mathrm{Pb}$ and $\mathrm{Zn}$ were in the available fractions (carbonate, $\mathrm{Fe} / \mathrm{Mn}$ oxide and organic). $\mathrm{Cu}$ was highest in the Fe/Mn oxide and organic fractions. This indicated that an increase in organic matter and reducing agents will avail the $\mathrm{Cu}$. $\mathrm{Zn}$ was distributed in all fractions while $\mathrm{Pb}$ was found in the $\mathrm{Fe} / \mathrm{Mn}$ oxide fraction (3.93- $21.3 \%$ ). Results showed that the bioavailability of $\mathrm{Cu}, \mathrm{Pb}$ and $\mathrm{Zn}$ was high. Metal bioavailability by BCR indicates a potential risk of pollution in lagoon sediments as the available metals exceeded the permissible Sediment Quality Assessment Guidelines (SQAG's) from Environmental Protection Agency (EPA).
\end{abstract}

Keywords: bioavailability, heavy metals, BCR extraction, lagoon, sediments

\section{Introduction}

Heavy metals $(\mathrm{Cd}, \mathrm{Cr}, \mathrm{Cu}, \mathrm{Pb}, \mathrm{Hg})$ are toxic at elevated concentrations and may cause health problems to users of water from lagoon, reservoirs, dams and wells which has been exposed to metal input (Musyoka et al., 2013). Sources of metal pollutants include weathering of soil, waste water discharge, solid waste deposited into the lagoon by surface runoff transporting pollutants (Grabowski et al., 2001; Jain, 2004; Singh et al., 2005). Metals settle in sediments and bind through processes of adsorption, ion exchange and precipitation (Filgueiras et al., 2002). They are released depending on a number of factors, that include $\mathrm{pH}$, conductivity, salinity, total dissolved solids, temperature and turbidity (Ramirez et al., 2005) (Calmano et al., 1993). For example a slightly acidic environment may increase the availability of metals, as most metals are soluble in acid more than alkaline, however $\mathrm{Cr}$ is reported to have high mobility in alkaline environments (Babale et al., 2011).

It is well established that total metal concentration is not an indicator of mobility or toxicity to living organisms. Bioavailability studies are used to measure metal mobility and bioavailability in the environment (Adriano, 2001). This involves fractionation of the total metal contaminant using chemical extraction procedures (Jain, 2004). To assess how metals are partitioned and their availability for uptake, single or selective extractants are used (Adriano, 2001). The extractants are chosen based on selectivity, precipitation and adsorption. Chemical sequential extractions are most commonly used to evaluate metal partitioning and mobility in sediment (Davidson et al., 1998; Margu1 et al., 2004). 
The most common and widely used sequential extraction was first developed by Tessier et al. (1979) (Baffi et al., 1998; Tessier et al., 1979). This method involves exposing the sample to the selected extractants in order to leach out the metals depending on their partitioning. The Tessier sequential procedure releases metals from five fractions. The fractions are metals bound to the exchangeable, carbonates, Fe/Mn oxides, organic matter and residual. A standardised sequential extraction procedure, the BCR sequential extraction is used for extraction of metals in soils and sediments (Ho et al., 1997). The BCR sequential extraction assists in identifying and quantifying different defined species, forms or phases in which an element occurs in the material (Van Herreweghe et al., 2003).

There may be the release of the metals due to ion exchange as these weakly adsorbed metals are held by weak electrostatic force. Low $\mathrm{pH}$ accelerates the mobility as it breaks the carbonate structure and increases the solubility of metals making them bioavailable to the living organisms (Atwell et al., 1999; Kazi et al., 2005). Metals bound to other fractions typically require a change in environmental conditions to become available.

The metals can be mobilised by an influx of reducing conditions in the environment (Kazi et al., 2005). Metals bound to the organic phase are more difficult to mobilise as a result of metals forming strong complexes with organic compounds in an oxidising environment (Atwell et al., 1999). The residual phase is the unreactive or the non-available phase, which is mostly bound to the silicate and can be made available from weathering (Filgueiras et al., 2002) (Farkas et al., 2007; Ianni et al., 2000; Ianni et al., 2001).

Numerous studies have been carried out using the BCR sequential extraction procedure for measuring the mobility of $\mathrm{Pb}, \mathrm{Cd}, \mathrm{Cr}, \mathrm{Cu}$ and $\mathrm{Zn}$ (Coetzee, 1993; Filgueiras et al., 2004; Singh et al., 2005). In Nigeria sediment quality studies have been carried out in some rivers, dams and estuaries. These were done by analysis of the physical parameters, particle size distribution and metal pollutants. The amount of metal contaminant that is bioavailable was measured by the amount accumulated in an organism (especially fish) and this was used as a measure of toxicity (Wepener et al., 2011). There is limited data on the bioavailability of metals in Nigeria lagoon sediments. Analysis must be undertaken to understand the chemical behaviour of metals and their impact on the environment. Therefore, it will require study into its pollution status and potential impact using bioavailable metal information (Howard et al., 1995). This study investigates the seasonal bioavailability of $\mathrm{Cd}, \mathrm{Cr}, \mathrm{Cu}, \mathrm{Pb}$ and $\mathrm{Zn}$. To the best of our knowledge, no data is available in literature on the bioavailability of these metals in the University Lagoon.

\section{Materials and Methods}

\subsection{Study Area}

The University of Lagos also called UNILAG, situated within Lagos Mainland LGA of Lagos state lies between latitude $03.2343^{\circ} \mathrm{E}-03.34554^{\circ} \mathrm{E}$ and longitude $06.2135^{\circ} \mathrm{N}-06.4323^{\circ} \mathrm{N}$. It is bounded on the north by Bariga, at the south by Onike and Iwaya, the east by Lagos Lagoon and at the west by Yaba.

The University of Lagos is an institution of higher learning founded in 1962. It presently has three campuses in Yaba and Surulere. The main campus which is of interest in this research is located at Akoka North eastern part of Yaba in Lagos Mainland LGA. It is largely surrounded by the scenic view of the Lagos Lagoon and with an area of 802 acres of land. 


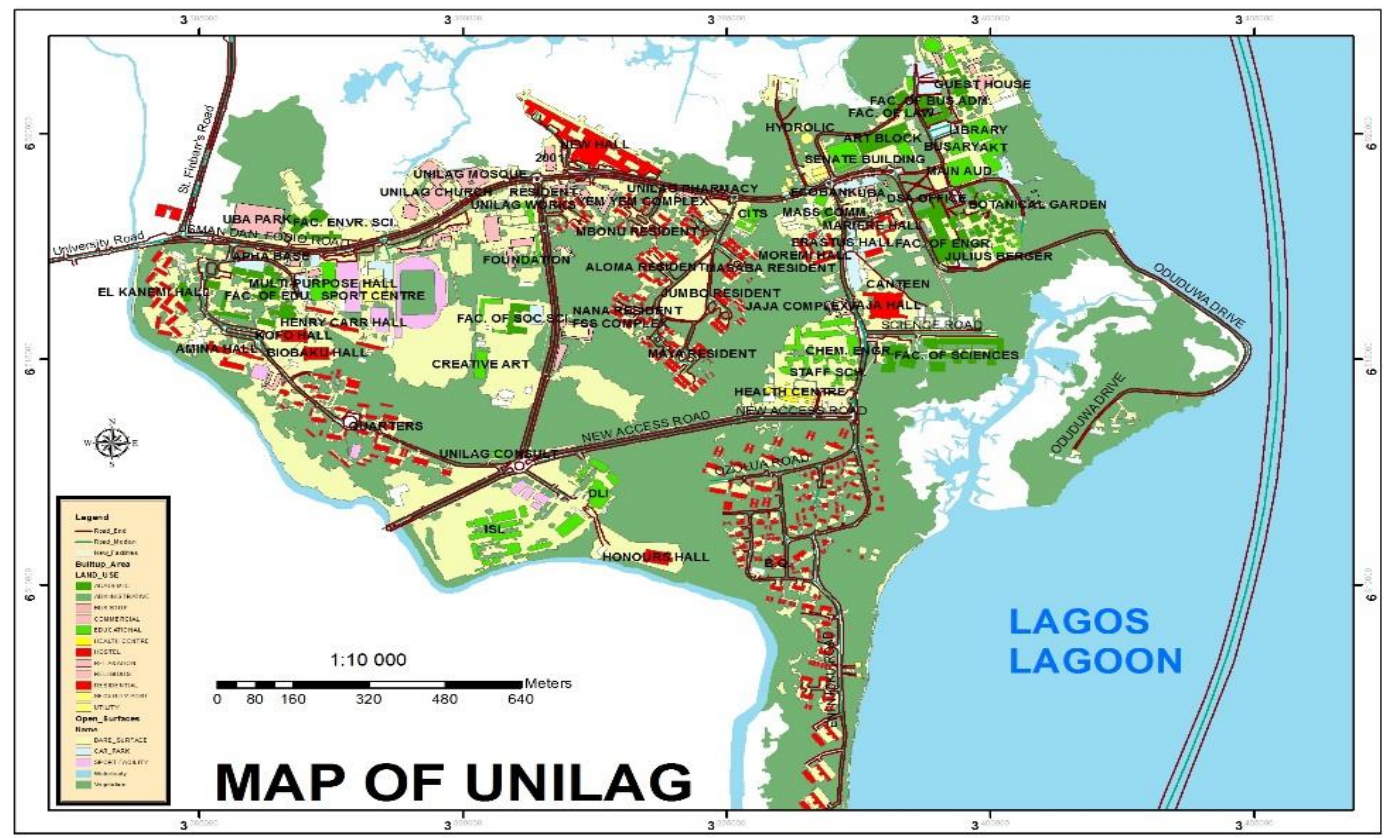

Figure 1: Existing digital map of UNILAG (Source: Department of Geography, university of Lagos.)

\subsection{Experimental}

1. Exchangeable

2. Fe/Mn oxide

3. Organic

4. Residual
$20 \mathrm{~mL}$ of 0.11 molL-1 HOAc, was added to the samples and shaken overnight for $16 \mathrm{~h}$ at $25^{\circ} \mathrm{C}$. The samples were centrifuged at SPEED and supernatant was refrigerated for analysis.

The residue from step 1 was treated with $20 \mathrm{~mL}$ of 0.5 molL-1 NH2OH.HCL and shaken overnight for $16 \mathrm{~h}$ at $25^{\circ} \mathrm{C}$. Centrifuging was done as in step 1.

$5 \mathrm{~mL}$ of $\mathrm{H} 2 \mathrm{O} 2$ at $85^{\circ} \mathrm{C}$ was added to the residue from step 2: then first hour manual shaking with uncovered vessel and last hour with a covered vessel, $25 \mathrm{~mL}$ of 1.0 molL-1 NH4OAc was later added and the samples were shaken for $16 \mathrm{~h}$ at $25^{\circ} \mathrm{C}$. Centrifuging was done

Samples were digested with aqua regia 3:1 ( $\mathrm{HCl}$ : HNO3)

The extracts from each step were analysed using ICP-OES (Perkin Elmer 5300 DV). Analysis of variance (ANOVA) was done for seasonal variations, $\mathrm{p}<0.05$.

\section{Results and discussion}


Statistical analysis (one way-ANOVA) for the total metals showed that there was no significant difference between spring and summer and between winter and autumn. However, there is a significant difference between the dry season and wet season. Therefore we present data from 1 season from each grouping. The data presented shows wet and dry season extractions to represent the dry and wet season respectively.

\subsection{Quality Assurance}

The method was validated (Table 4) with the CRM. The percentage RSD was typically <3\%.

Table 1: Experimental and certified (bold) values for the certified reference material BCR 701

\begin{tabular}{|l|l|l|l|}
\hline Metal & Step 1 & Step 2 & Step 3 \\
\hline $\mathrm{Cd}$ & $8.1 \pm 0.1$ & $3.65 \pm 0.01$ & $0.24 \pm 0.03$ \\
& $\mathbf{7 . 3} \pm \mathbf{0 . 4}$ & $\mathbf{3 . 7 7} \pm \mathbf{0 . 2 8}$ & $\mathbf{0 . 2 7} \pm \mathbf{0 . 0 6}$ \\
\hline $\mathrm{Cr}$ & $2.29 \pm 0.02$ & $38.2 \pm 0.2$ & $114 \pm 1$ \\
& $\mathbf{2 . 2 6} \pm \mathbf{0 . 1 6}$ & $\mathbf{4 5 . 7} \pm \mathbf{2}$ & $\mathbf{1 4 3} \pm \mathbf{7}$ \\
\hline $\mathrm{Cu}$ & $59.0 \pm 1.3$ & $108 \pm 0.4$ & $49 \pm 2$ \\
& $\mathbf{4 9 . 3} \pm \mathbf{1 . 7}$ & $\mathbf{1 2 4} \pm \mathbf{3}$ & $\mathbf{5 5} \pm \mathbf{4}$ \\
\hline $\mathrm{Pb}$ & $3.50 \pm 0.09$ & $107 \pm 2$ & $7.6 \pm 0.1$ \\
& $\mathbf{3 . 1 8} \pm \mathbf{0 . 2 1}$ & $\mathbf{1 2 6} \pm \mathbf{3}$ & $\mathbf{9 . 3} \pm \mathbf{2}$ \\
\hline $\mathrm{Zn}$ & $233 \pm 2$ & $96 \pm 0.1$ & $53 \pm 0.6$ \\
& $\mathbf{2 0 5} \pm \mathbf{6}$ & $\mathbf{1 1 4} \pm \mathbf{5}$ & $\mathbf{4 6} \pm \mathbf{4}$ \\
\hline
\end{tabular}

Values in $\mathrm{mg} \mathrm{kg}-1$

\subsection{Physico-chemical parameters}

The results (Table 5) show the physico- chemical parameters. The $\mathrm{pH}$ ranges from 6 to 8 which is typical for river water (Babale et al., 2011).

Table 2: Physico- chemical parameters

\begin{tabular}{|l|l|l|l|l|l|l|l|l|}
\hline $\begin{array}{l}\text { Sit } \\
\text { e } \\
\text { cod } \\
\text { e }\end{array}$ & $\begin{array}{l}\text { Seas } \\
\text { ons }\end{array}$ & pH & $\begin{array}{l}\text { Temperat } \\
\text { ure/ }{ }^{\circ} \mathrm{C}\end{array}$ & Eh/mV & $\begin{array}{l}\text { TDS/ } \\
\text { mg L-1 }\end{array}$ & $\begin{array}{l}\text { DO/ } \\
\text { mg L-1 }\end{array}$ & $\begin{array}{l}\text { EC/ } \\
\mu S \text { cm-1 }\end{array}$ & $\begin{array}{l}\text { Salinity/ } \\
\text { mg L-1 }\end{array}$ \\
\hline $\mathbf{A}$ & Wet & 6.02 & 14.8 & 80 & 440 & 11.2 & 860 & 0.2 \\
\hline dry & 6.04 & 24.2 & 35 & 18 & 6 & 31.2 & 0 \\
\hline B & Wet & 6.79 & 15.3 & 49 & 395 & 10.5 & 772 & 0.1 \\
\hline Dry & 6.84 & 26 & 74 & 26 & 6.6 & 45.4 & 0 \\
\hline C & Wet & 6.47 & 16.4 & 73 & 396 & 9.6 & 774 & 0.1 \\
\hline Dry & & 6.6 & 25.6 & 130 & 26 & 6.75 & 45.4 & 0 \\
\hline D & Wet & 6.38 & 16.3 & 79 & 400 & 10.7 & 702 & 0.1 \\
\hline Dry & & 6.77 & 25.7 & 115 & 26 & 6.9 & 48.6 & 0 \\
\hline $\mathbf{E}$ & Wet & 6.38 & 15 & 158 & 48 & 2 & 1000 & 0 \\
\hline
\end{tabular}




\begin{tabular}{|l|l|l|l|l|l|l|l|l|}
\hline Dry & & 6.59 & 25.3 & 97 & 28 & 5.8 & 47 & 0 \\
\hline F & Wet & 7.1 & 16.1 & 55 & 562 & 2.9 & 1269 & 0.3 \\
\hline Dry & & 7.38 & 26.2 & 60 & 44 & 6.1 & 75.8 & 0 \\
\hline G & Wet & 7.25 & 17.3 & 59 & 1594 & 3.7 & 5690 & 1.5 \\
\hline Dry & & 7.47 & 26.3 & 58 & 88 & 6.6 & 151.7 & 0 \\
\hline H & Wet & 6.6 & 15.4 & 44 & 820 & 1.2 & 1440 & 0.6 \\
\hline Dry & & 7.24 & 24.4 & 8 & 69 & 6.6 & 118.5 & 0 \\
\hline
\end{tabular}

\subsection{Extractable metals}

The BCR extraction showed $\mathrm{Cd}$ and $\mathrm{Cr}$ mostly in the residual fraction. The behaviour has been shown to be typical for these two metals (Babale et al., 2011; Kartal et al., 2006). Seasonally winter had the highest number of metals in the potentially available fractions and when exposed to changes in the environment these metals will become available.

High temperatures in the wet season increase the rate of chemical weathering which in turn release metals and through runoff are deposited in solubilised form into the river (Dekov, Komy, Araújo, et al., 1997). Some data presented will be explained using the physical parameters as studies have shown that they influence the bioavailability of metals (Sauve et al., 2000).

\subsubsection{Cadmium}

The distribution of $\mathrm{Cd}$ was in the following order; residual> organic > exchangeable $\sim \mathrm{Fe} / \mathrm{Mn}$ oxide. This was observed in the wet season where $\mathrm{Cd}$ was in high concentration whereas in the dry season most of the measurements were below the detection limit. Though the $\mathrm{Cd}$ concentration was high in the wet season, it was mostly in the residual fraction (not available). The $\mathrm{Cd}$ concentration that was in the available fractions (carbonate, Fe/Mn oxide and organic) were consistent throughout ranging from 2.0 to $3.0 \mathrm{mg} \mathrm{kg}-1$. All sites showed $\mathrm{Cd}$ input from residential to industrial areas as $\mathrm{Cd}$ ions immediately discharged from point sources are absorbed into the sediment as they are not mobile over long distances. When the ions are detected in high concentrations in the carbonate phase, it generally implies that a nearby source had some influence (Tsai et al., 2007).

$\mathrm{Cd}$ in the exchangeable fraction meant that it was held by weak electrostatic forces and can be removed by ion exchange (Babale et al., 2011). The EPA Sediment Quality Assessment Guideline (SQAG) value for $\mathrm{Cd}$ in river sediment is $0.676 \mathrm{mg} \mathrm{kg}-1$ (FDEP, 1994). This indicates that $\mathrm{Cd}$ in the exchangeable fraction has a possibility of negatively impacting the biological processes of the ecosystem as it is exceeding the limit value (Klavinš et al., 2000). It has also been shown in other bioavailability studies that even though Cd exists in low concentrations, it is found mostly in the exchangeable phase and is bound to carbonates (Gunther et al., 2005; Tsai et al., 2002). Metals bound to carbonates (acid soluble fraction) are susceptible to $\mathrm{pH}$ changes but in this case Cd bioavailability will not be highly influenced by $\mathrm{pH}$ because it is in the optimum level (6-8).

\subsubsection{Chromium}

$\mathrm{Cr}$ was found mostly in the residual fraction meaning that it is retained in the crystalline structure and not bioavailable (Kazi et al., 2005). It has relatively low amounts in the Fe/Mn oxide fraction, followed by organic and finally exchangeable fractions for all seasons (Figure 2). The available fractions do not exceed the EPA SQAG permissible value of $52.3 \mathrm{mg} \mathrm{kg}-1$ therefore there is low toxicity. As shown in Figure 2, $\mathrm{Cr}$ in winter from the industrial zone was predominantly in the organic fraction whereas in summer it was in the Fe/Mn oxide fraction.

$\mathrm{Cr}$ is used in industries and if deposited as hazardous waste into the lagoon, the metal oxides that is $\mathrm{CrO} 2$ will flow with the water and some particulates settle in the sediments (Metze et al., 2005). There is a 
possibility of $\mathrm{Cr}$ input entering from the waste sludge which flushes down the catchment until it reaches the ocean.

Cr exists as $\mathrm{Cr}$ (III) and $\mathrm{Cr}$ (VI) states and its bioavailability is dependent on the chemical state. The highly soluble, more toxic and bioavailable form of $\mathrm{Cr}$ is $\mathrm{Cr}$ (VI) (Dirilgen et al., 2002). Both of them are predominant and highly available in humic environments, but $\mathrm{Cr}(\mathrm{VI})$ in acidic solution has a high redox potential which shows that it is strongly oxidising and unstable in the presence of electron donors for example organic matter (Metze et al., 2005). The $\mathrm{pH}$ in dry season is approximately 6.0 which is weakly acidic and high redox potential up to $130 \mathrm{mV}$, therefore these can avail $\mathrm{Cr}$ (VI) that is bound to the $\mathrm{Fe} / \mathrm{Mn}$ oxide phase.

\subsubsection{Copper}

Sediments typically have high concentrations of $\mathrm{Cu}$ in the wet season (Dekov, Komy, Araújo, et al., 1997). $\mathrm{Cu}$ was predominantly in the organic and residual phase in the dry season (Figure 3) making its potential mobility to be limited. In addition these partitioned stable complexes are highly mobile and toxic (Artiola, 2005). $\mathrm{Cu}$ bound to the organic fraction in the dry season has the highest percentage (32\% of the total concentration). The stable $\mathrm{Cu}$ organic complex can be described by anion exchange from binding with hydroxyl and carbonyl functional groups (Iwegbue, 2011) (Coetzee, 1993).

$\mathrm{Cu}$ in the dry season has a possibility of being bioavailable under oxidising conditions and can be toxic to the ecosystem. The metals bound to organic matter will be released into the environment by oxidising agents (decomposition processes) (Artiola, 2005). $\mathrm{Cu} 2+$ is usually adsorbed onto clays especially Fe/Mn oxide while the stable $\mathrm{Cu}$ is mostly in organic soils. In the wet season $\mathrm{Cu}$ was consistently associated with the $\mathrm{Fe} / \mathrm{Mn}$ oxide fraction. The EPA SQAG permissible limit for $\mathrm{Cu}$ in river sediments is $18.7 \mathrm{mg} \mathrm{kg}-1$ (FDEP, 1994). For highly mobile soluble $\mathrm{Cu}$ the levels are below the permissible EPA SQAG limit which indicates less toxicity.

\subsubsection{Lead}

$\mathrm{Pb}$ is predominantly in the $\mathrm{Fe} / \mathrm{Mn}$ oxide phase (Figure 4) in the wet season and mostly unavailable in dry season. This shows that in winter $\mathrm{Pb} 2+$ is able to replace $\mathrm{Fe} 2+$ in the Fe/Mn oxide because of the adsorbing capacity and surface area (Iwegbue, 2011). High concentrations of $\mathrm{Pb}$ will be bioavailable depending on the reducing conditions and changes in redox conditions. Our data follows the reported trend that Fe/Mn oxide fraction has a high affinity of $\mathrm{Pb}$ in the dry season (Fonseca et al., 2013). The available $\mathrm{Pb}$ partitioned to carbonates in the dry season is below the EPA SQAG permissible limit (30.2 mg kg-1) hence there is low toxicity threat.

In the wet season $\mathrm{Pb}$ was in the residual fraction indicating that it is not bioavailable. However if the $\mathrm{Pb}$ Fe-Mn-oxide phase become available; the concentration of $\mathrm{Pb}$ would be above the permissible levels and would pose a threat to the environment. These results are in agreement with another study on seasonal bioavailability of $\mathrm{Pb}$ in sediments which showed that $\mathrm{Pb}$ was mostly in the Fe/Mn oxide phase in the dry season as compared to the wet season (Iwegbue, 2011).

\subsubsection{Zinc}

$\mathrm{Zn}$ is distributed in all the fractions (Figure 4). Soluble $\mathrm{Zn}$ attaches to Fe/Mn oxides or organic matter and the mobility and availability is dependable on $\mathrm{pH}$ (Balintova et al., 2012). When the $\mathrm{pH}$ is basic the metal is likely to be mobile and bioavailable. Concentrations of $\mathrm{Zn}$ range from; 3.48- 302 (exchangeable), Fe/Mn oxide (1.08- 95.51), organic (1.09-23.62) and residual phases (1.05- 259.35) mg kg-1, the year through. In the dry season $\mathrm{Zn}$ was consistently unavailable until sites $\mathrm{G}$ and $\mathrm{H}$ where $\mathrm{Zn}$ was primarily bound to the carbonate fraction. The percentage of $\mathrm{Zn}$ in the carbonate fraction was $64.4 \%$ and $44.2 \%$ of the total metal concentration for sites $\mathrm{G}$ and $\mathrm{H}$ respectively. This indicated that a high amount of $\mathrm{Zn}$ in the lower catchment was bioavailable. The same trend was observed in the wet season except that from A to F $\mathrm{Zn}$ had an association with the Fe/Mn oxide and organic fractions. The abundance of $\mathrm{Zn}$ in the carbonate (easily 
mobilised) fraction in site $\mathrm{G}$ and $\mathrm{H}$ shows that there may be influence from the waste sludge management and on-going construction. This flushed down in summer yielding a decrease in total concentration but not percentage contribution. It can be concluded that $\mathrm{Zn}$ is a pollutant and primarily from anthropogenic sources. The concentrations are exceeding the EPA SQAG value of $124 \mathrm{mg} \mathrm{kg-1}$ (FDEP, 1994) which shows that the $\mathrm{Zn}$ will be toxic to the ecosystem. $\mathrm{Zn}$ will be highly bioavailable as the $\mathrm{pH}$ and redox in the sediment changes (Iwegbue, 2011).

\section{Conclusion}

Due to the nature of the areas along the lagoon, it is difficult to point out the reasons for the variations. Many activities may be affecting the natural balance of the lagoon and these include informal settlements, industries, illegal dumpsites and commercial zones. Heavy metals $\mathrm{Cd}, \mathrm{Cr}, \mathrm{Cu}, \mathrm{Pb}$ and $\mathrm{Zn}$ were extracted and bioavailable in different seasons and sampling sites. $\mathrm{Cd}$ and $\mathrm{Cr}$ were mostly in the residual fraction; this meant that the metals were not available. Low traces of $\mathrm{Cr}$ were found in the $\mathrm{Fe} / \mathrm{Mn}$ oxide phase in summer while $\mathrm{Cd}$ was in the exchangeable phase only in winter. Generally seasonal variability of these metals showed winter having more metals that is $\mathrm{Cd}, \mathrm{Cu}, \mathrm{Pb}$ and $\mathrm{Zn}$ in the available fractions. Metals in the exchangeable fraction like $\mathrm{Cd}$ and $\mathrm{Zn}$ which is predominant in most sampling sites are toxic to organisms. This is so as they can easily be moved, therefore, bioavailable to organisms in the ecosystem. The organic phase is also toxic as the metals are easily solubilised when the environmental conditions change. Change in the environment $\mathrm{pH}$, redox potential, conductivity and anion concentration will solubilise the metals making them bioavailable thus subjecting University Lagoon to be a danger zone to living organisms.

\section{Acknowledgement}

This research was made possible by the University of Lagos, Faculty of Science Akoka, Lagos.

6. Conflict of Interest: the authors declare no competing interest

\section{References}

Abdul-Kareem, B. M., Rabee A.M., \& Al-Fatlawy Y.F. (2011). Monitoring heavy metals, cations and anions levels and its possible health risks in Tigris River at Baghdad region. Iraqi Journal of Science, 52(3), 306-316.

Adeniyi, A., Dayomi, M., Siebe, P., \& Okedeyi, O. (2008). An assessment of the levels of phthalate esters and metals in the Muledane open dump, Thohoyandou, Limpopo Province, South Africa. Chemistry Central Journal, 2(9).

Adriano, D. C. (2001). Trace elements in terrestrial environments: biogeochemistry, bioavailability and risks of metals ( 2 ed.). New York, USA: Springer.

Agarwal, S. K. (2009). Heavy metal pollution Vol. 4. (pp. 37-71). Retrieved from http://books.google.co.za/books?hl=en\&lr=\&id=nmputkzWWkkC\&oi=fnd\&pg=PR5\&dq=Heavy+metal+ pollution+by+Agarwal+S+K\&ots=SdHT21I2dY\&sig=S7U_BhEnnbDnDrULAQPoQdDrWrk\#v=onepag e\&q=Heavy\%20metal\%20pollution\%20by\%20Agarwal\%20S\%20K\&f=false

Akcay, H., Oguz, A., \& Karapire, C. (2003). Study of heavy metal pollution and speciation in Buyak Menderes and Gediz river sediments. Water Research, 37(4), 813-822.

Alagarsamy, R. (2006). Distribution and seasonal variation of trace metals in surface sediments of the Mandovi estuary, west coast of India. Estuarine, Coastal and Shelf Science, 67(1-2), 333-339.

Artiola, J. F. (2005). Speciation of Copper. In H. C. R. Cornelis, J. Caruso, K. G. Heumann (Ed.), Handbook of elemental speciation II: Species in the environment, food, medicine and occupational health. England: John Wiley and sons.

Atwell, B. J., Kriedemann, P. E., \& Turnbul, C. G. N. (1999). Plants in Action: Adaptation in Nature, Performance in Cultivation. In D. P. E. K. Dr Brian J. Atwell., Dr. Colin G.N., Associate Prof. Derek 
Eamus ., Dr Roderick L ., Bieleski Prof. Graham Farquhar (Series Ed.) M. E. AU (Ed.) Retrieved from http://plantsinaction.science.uq.edu.au/edition1/?q=content/title-page

Audry, S., Schäfer, J., Blanc, G., \& Jouanneau, J.-M. (2004). Fifty-year sedimentary record of heavy metal pollution $(\mathrm{Cd}, \mathrm{Zn}, \mathrm{Cu}, \mathrm{Pb})$ in the Lot River reservoirs (France). Environmental Pollution, 132(3), 413-426.

Austin, R., \& Rhoades, J. (1979). A compact, low-cost circuit for reading four-electrode salinity sensors. Soil Science Society of America Journal, 43(4), 808-810.

Babale, A., Uzairu, A., Kagbu, J., Okunola, O., \& Abba, H. (2011). Assessment of Cd and Cr

Bioavailability in Sediment of River Challawa, Nigeria. British J. Appl. Sci. Technol, 1(3), 116-130.

Baffi, F., Ianni, C., Ravera, M., Soggia, F., \& Magi, E. (1998). Evaluation of the acetate buffer attack of a sequential extraction scheme for marine particulate metal speciation studies by scanning electron microscopy with energy dispersive X-ray analysis. Analytica Chimica Acta, 360(1), 27-34.

Balintova, M., Petrilakova, A., \& Singovszka, E. (2012). Study of Metals Distribution between Water and Sediment in the Smolnik Creek (Slovakia) Contaminated by Acid Mine Drainage. Chemical Engineering, 28.

Bandara, J. S., Wijewardena, H. P., Bandara, Y. Y., Jayasooriya, R. T., \& Rajapaksha, H. (2010).

Pollution of River Mahaweli and farmlands under irrigation by cadmium from agricultural inputs leading to a chronic renal failure epidemic among farmers in NCP, Sri Lanka. Environ Geochem Health, 33(439453). Banerjee, U., \& Gupta, S. (2012). Source and distribution of Lead, Cadmium, Iron and Manganese in the river Damodar near Asansol Industrial Area, West Bengal, India. International journal of Environmental Sciences, 2(3).

Barratt, G. J., Combrink, J.,. (2002). An assessment of the degree of mercury (Hg) bio-transformation in two river systems following discharges from a mercury recovery plant. Technikon Natal, Durban, South Africa.

Bartoli, G., Papa, S., Sagnella, E., \& Fioretto, A. (2012). Heavy metal content in sediments along the Calore river: Relationships with physical-chemical characteristics. Journal of Environmental Management, 95, Supplement(0), S9-S14.

Batista, B. L., Rodrigues, J. L., Nunes, J. A., Tormen, L., Curtius, A. J., \& Barbosa Jr, F. (2008). Simultaneous determination of $\mathrm{Cd}, \mathrm{Cu}, \mathrm{Mn}, \mathrm{Ni}, \mathrm{Pb}$ and $\mathrm{Zn}$ in nail samples by inductively coupled plasma mass spectrometry (ICP-MS) after tetramethylammonium hydroxide solubilization at room temperature: comparison with ETAAS. Talanta, 76(3), 575-579.

Bettinelli, M., Beone, G., Spezia, S., \& Baffi, C. (2000a). Determination of heavy metals in soils and sediments by microwave-assisted digestion and inductively coupled plasma optical emission spectrometry analysis. Analytica Chimica Acta, 424(2), 289-296.

Bettinelli, M., Beone, G. M., Spezia, S., \& Baffi, C. (2000b). Determination of heavy metals in soils and sediments by microwave-assisted digestion and inductively coupled plasma optical emission spectrometry analysis. Analytica Chimica Acta, 424(2), 289-296.

Binning, K., \& Baird, D. (2001). Survey of heavy metals in the sediments of the Swartkops River Estuary, Port Elizabeth South Africa. Water SA, 27(4), 461-466.

Blighnaut, J. N., Marais, C., \& Turpie, J. K. (2007). Determining a charge for the clearing of invasive alien plant species (IAP's) to augment water supply in South Afica. Water SA, 33(1).

Breslin, V. T., Clough, D., Cucchiarelli, D., Dart, P., Detelich, C., Guandal, S., . . Loman, P. (2005). Sediment Metal Contamination in the Branford River and Harbor.

Calmano, W., Hong, J., \& Foerstner, U. (1993). Binding and mobilization of heavy metals in contaminated sediments affected by $\mathrm{pH}$ and redox potential. Water Science \& Technology, 28(8), 223235.

Cesar, A., Choueri, R. B., Riba, I., Morales-Caselles, C., Pereira, C. D. S., Santos, A. R., . . DelValls, T. A. (2007). Comparative sediment quality assessment in different littoral ecosystems from Spain (Gulf of Cadiz) and Brazil (Santos and São Vicente estuarine system). Environment International, 33(4), 429-435. 
USEPA. (2012b). Water: contaminated sediments Technical resourcesguidelines.http://water.epa.gov/polwaste/sediments/cs/guidelines.cfm Van Herreweghe, S., Swennen, R., Vandecasteele, C., \& Cappuyns, V. (2003). Solid phase speciation of arsenic by sequential extraction in standard reference materials and industrially contaminated soil samples. Environmental Pollution, 122(3), 323-342.

Wepener, V., van Dyk, C., Bervoets, L., O’Brien, G., Covaci, A., \& Cloete, Y. (2011). An assessment of the influence of multiple stressors on the Vaal River, South Africa. Physics and Chemistry of the Earth, Parts A/B/C, 36(14), 949-962.

WRC. (2002). State of rivers report uMngeni River and neighbouring rivers and streams (W. A. a. Forestry \& E. A. a. Tourism, Trans.). In U. Water, e. Municipality, C. Environmentek \& U. o. Natal (Eds.), Product of the river health. Pretoria, South Africa

Wright, P., \& Mason, C. F. (1999). Spatial and seasonal variation in heavy metals in the sediments and biota of two adjacent estuaries, the Orwell and the Stour, in eastern England. Science of the total environment, 226(2-3), 139-156.

Wuana, R. A., \& Okieimen, F. E. (2011). Heavy Metals in Contaminated Soils: A Review of Sources, Chemistry, Risks and Best Available Strategies for Remediation. ISRN Ecology, 2011, 20.

Ye, F., Huang, X., Zhang, D., Tian, L., \& Zeng, Y. (2012). Distribution of heavy metals in sediments of the Pearl River Estuary, Southern China: Implications for sources and historical changes. Environmental Sciences, 24(4), 579-588.

Zeisler, R. (2004). New NIST sediment SRM for inorganic analysis. Analytical and bioanalytical chemistry, 378(5), 1277-1283.

Zhang, W., Yu, L., Lu, M., Hutchinson, S. M., \& Feng, H. (2007). Magnetic approach to normalizing heavy metal concentrations for particle size effects in intertidal sediments in the Yangtze Estuary, China. Environmental Pollution, 147(1), 238-244.

Zimmerman, A. J., \& Weindorf, D. C. (2010). Exraction: A review of procedures. Analytical Chemistry, 20. 